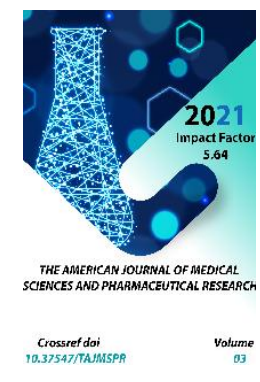

Copyright: Original content from this work may be used under the terms of the creative commons attributes 4.0 licence.

\section{Analysis Of The Assortment Of Drugs With A Sedative Effect}

Xidoyatova Zulfiya Sharifovna

Ds Department Of Pharmaceutical Organization Tashkent Pharmaceutical Institute, Uzbekistan

\section{Azimova Nozima Akramovna}

Assistant, Department Of Pharmaceutical Organization Tashkent Pharmaceutical Institute, Uzbekistan

\section{Azimova Munira Takhirovna}

Assistant, Department Of Pharmaceutical Organization Tashkent Pharmaceutical Institute, Uzbekistan

\title{
ABSTRACT
}

A content analysis of the pharmaceutical market range of drugs with sedative effect was conducted. In the analysis of drugs with sedative effect, "West trade", "Floromed", "Grand farm", "Tabletka", "Dava", "Shafran farm", "Glucose", "Tetra", "Kobiljon Obidjon", "Pharmacy diabetes", "Navbahor", "777 pharmacy", "999 pharmacy", "pharmacy Malikabonu" pharmacies, the Department of neurology of the II clinic of the Tashkent Medical Academy, the State Department of medicines and medical products the basis of the register was. Determination of the share of products of manufacturing enterprises in the pharmaceutical market was the main objective of the study carried out.

\section{KEYWORDS}

Drugs with sedative effect, enterprises of local production, update index, assortment, content analysis.

\section{INTRODUCTION}

Since ancient times, sedative drugs have been used for the purpose of treating diseases of the nervous system. They mainly affect the functional activity of the brain, thereby disrupting braking. This group of drugs does not have a sleeping effect, but relaxes the onset of sleep. Has no side effects. Psychological or physical dependence does not call for such characteristics as getting used to sedative drugs. From the literature data it 
became known that sedative drugs are the most" ancient " drugs, they are being used to treat diseases of the nervous system. The modern pharmaceutical market in Uzbekistan is characterized by the growth of their nomenclature.

To conduct a content analysis of sedative drugs, we mainly used the data of the state register of medicines and medical products for 2019 year 23. During the research, the total amount of sedative drugs allowed to be used in our republic until now was calculated and on this basis the analysis of the assortment on state-owned enterprises was carried out.

During the analysis, it was found that about 100 types of sedative drugs were recorded in the state register under the trade name. Of these, 49 (49\%) corresponded to domestic production enterprises, 27 (27\%) correspond to the production enterprises of independent Commonwealth states, 24 (24\%) correspond to the enterprises of foreign countries.

Table 1

\section{Analysis of the assortment of sedative drugs included in the State Register of medicines} and medical products

\begin{tabular}{|c|c|c|c|c|c|}
\hline № & $\begin{array}{c}\text { State Register Of } \\
\text { The Republic Of } \\
\text { Uzbekistan }\end{array}$ & $\begin{array}{c}\text { Locally } \\
\text { produced drugs }\end{array}$ & $\begin{array}{c}\text { Drugs } \\
\text { produced by } \\
\text { the CIS } \\
\text { countries }\end{array}$ & $\begin{array}{c}\text { Medicines } \\
\text { from abroad }\end{array}$ & Total \\
\hline $\mathbf{1}$ & №21(2017) & 45 & 25 & 21 & 91 \\
\hline $\mathbf{2}$ & №22(2018) & 43 & 24 & 21 & 88 \\
\hline 3 & №23(2019) & 49 & 27 & 24 & 100 \\
\hline
\end{tabular}

According to the results of the content analysis, the names of new sedative drugs are noted in the pharmaceutical market of Uzbekistan.

The form of production of drugs, the structure of sedative drug preparations according to the producing countries were studied. From the pharmacies, whose names were mentioned above, the average price of the most commonly used sedative drugs was determined. 
Table 2

\section{Average retail price analysis of sedative drugs}

\begin{tabular}{|c|c|c|c|c|}
\hline № & $\begin{array}{c}\text { Name of sedative } \\
\text { drugs }\end{array}$ & Form of the drug & $\begin{array}{l}\text { Name of the } \\
\text { manufacturer }\end{array}$ & $\begin{array}{l}\text { Average retail } \\
\text { price } \\
\text { (in sum) }\end{array}$ \\
\hline 1 & Valerian nastoyka & $\begin{array}{l}25 \mathrm{ml}, 40 \mathrm{ml}, 50 \mathrm{ml} \\
\text { in bottle }\end{array}$ & $\begin{array}{l}\text { Radiks, NPP } \\
\text { Uzbekistan }\end{array}$ & 2000 \\
\hline 2 & Valerian nastoyka & $\begin{array}{l}20 \mathrm{ml}, 25 \mathrm{ml}, 40 \mathrm{ml}, \\
50 \mathrm{ml} \text { in bottle }\end{array}$ & $\begin{array}{l}\text { Remedy Group, } \\
\text { SPOOO English-British } \\
\text { United Kingdom }\end{array}$ & 2300 \\
\hline 3 & Valerian nastoyka & $\begin{array}{l}15 \mathrm{ml}, 20 \mathrm{ml}, 25 \mathrm{ml} \text {, } \\
40 \mathrm{ml}, 50 \mathrm{ml} \text { bottle }\end{array}$ & $\begin{array}{c}\text { Galenika, OOO } \\
\text { Uzbekistan }\end{array}$ & 1500 \\
\hline 4 & Valerian nastoyka & $\begin{array}{l}25 \text { ml bottle, } 20 l, \\
60 \text { L bottle }\end{array}$ & $\begin{array}{l}\text { Neogalen Farm, } \\
\text { IPOOO Uzbekistan }\end{array}$ & 2700 \\
\hline 5 & Valerian nastoyka & In $25 \mathrm{ml}$ of bottle & $\begin{array}{c}\text { Biatan, OOO } \\
\text { Uzbekistan } \\
\end{array}$ & 4700 \\
\hline 6 & Valerian nastoyka & $\begin{array}{c}25 \mathrm{ml}, 40 \mathrm{ml}, 50 \mathrm{ml} \\
\text { in Bottle }\end{array}$ & $\begin{array}{c}\text { Aktash, CHP } \\
\text { Uzbekistan }\end{array}$ & 3500 \\
\hline 7 & Valerian extract & $\begin{array}{l}\text { Table 2omg №10, № } \\
\text { 25, №50 (contour } \\
\text { leaf packaging) }\end{array}$ & $\begin{array}{c}\text { Nika farm, DXO } \\
\text { Uzbekistan }\end{array}$ & 1800 \\
\hline 8 & Valerian Bel med & $\begin{array}{c}\text { Tabletka } 200 \mathrm{mg} \\
\text { № } 10, \text { №20, № } 30, \\
\text { №50 (contour yacht } \\
\text { package) }\end{array}$ & $\begin{array}{l}\text { Belarusian bel med } \\
\text { preparations, RUP }\end{array}$ & 1500 \\
\hline 9 & Valerian nastoyka & $30 \mathrm{ml}$ & $\begin{array}{c}\text { Medicinal preparations } \\
\text { Borisov plant, OAO } \\
\text { Belarus }\end{array}$ & 1600 \\
\hline 10 & Valerian extract & $\begin{array}{l}\text { 20mg shell-coated } \\
\text { sachet №10, № } 50 \\
\text { (contour leaf } \\
\text { packaging) }\end{array}$ & $\begin{array}{c}\text { Dalhim farm, OAO } \\
\text { Russia }\end{array}$ & 1500 \\
\hline 11 & Korovinia & $\begin{array}{c}\text { Drops } 25 \mathrm{ml} \text { in a } \\
\text { bottle }\end{array}$ & Farmak, OAO Ukraine & 6000 \\
\hline 12 & Corvale & $\begin{array}{c}\text { Tablet № } 10,30,50 \\
\text { blisters }\end{array}$ & Farmak, OAO Ukraine & 6500 \\
\hline 13 & Corvale & $\begin{array}{c}\text { Drops } 25 \mathrm{ml} \text { in a } \\
\text { bottle }\end{array}$ & Farmak, OAO Ukraine & 6200 \\
\hline
\end{tabular}


The American Journal of Medical Sciences and Pharmaceutical Research

(ISSN - 2689-1026)

MPACT FACTOR

Published: January 22, 2021 | Pages: 81-86

2021: 5.64

Doi: https://doi.org/10.37547/TAJMSPR/Volume03Issue01-12

OCLC - 1121105510

\begin{tabular}{|c|c|c|c|c|}
\hline 14 & Korvaltap & Tablet №20 blister & $\begin{array}{c}\text { Start of Farma, OOO } \\
\text { Ukraine }\end{array}$ & 2000 \\
\hline 15 & Fitused & Capsules №20 & $\begin{array}{c}\text { XFZ in Krasnaya } \\
\text { Zvezda, Pao Ukraine }\end{array}$ & 3500 \\
\hline 16 & Fitused & $\begin{array}{c}100 \text { ml nastoyka } \\
\text { bottle }\end{array}$ & $\begin{array}{l}\text { Tbilisi pharmaceutical } \\
\text { plant, OOO Georgia }\end{array}$ & 3600 \\
\hline 17 & Fitused & $25 \mathrm{ml}$ drops & $\begin{array}{l}\text { Tbilisi pharmaceutical } \\
\text { plant, OOO Georgia }\end{array}$ & 3400 \\
\hline 18 & Gardialex & $\begin{array}{c}\text { Nastoyka } 25 \mathrm{ml}, \\
50 \mathrm{ml}\end{array}$ & $\begin{array}{c}\text { Aktash, CHP } \\
\text { Uzbekistan }\end{array}$ & 6000 \\
\hline 19 & Gardiastim & $\begin{array}{l}\text { Nastoyke } 25 \mathrm{ml} \text {, } \\
30 \mathrm{ml}, 40 \mathrm{ml}, 50 \mathrm{ml}\end{array}$ & Biatan, 000 & 4500 \\
\hline 20 & Postirnik & $\begin{array}{c}\text { Nastoyke } 25 \mathrm{ml}, \\
\text { 30ml, 40ml, 50ml }\end{array}$ & Grace Pharma, OOO & 1000 \\
\hline 21 & Sedavit & Tablet №2o blister & $\begin{array}{c}\text { Kievmedpreparat, Pao } \\
\text { Ukraine }\end{array}$ & 31000 \\
\hline 22 & Sedavit & $\begin{array}{c}\text { In } 100 \mathrm{ml} \text {, in } 200 \mathrm{ml} \\
\text { bottle }\end{array}$ & $\begin{array}{c}\text { Galichfarm, Pao } \\
\text { Ukraine }\end{array}$ & 32000 \\
\hline 23 & Sedistress & Tablet №30 blister & $\begin{array}{c}\text { Start of Farma, OOO } \\
\text { Ukraine }\end{array}$ & 23000 \\
\hline 24 & Vamelan & $\begin{array}{l}\text { Capsules №30 } \\
\text { blister }\end{array}$ & $\begin{array}{c}\text { World Medicine, } \\
\text { England produced } \\
\text { Poland }\end{array}$ & 37000 \\
\hline 25 & Dormant & $\begin{array}{c}\text { Homeopathic diet } \\
\text { №150 }\end{array}$ & $\begin{array}{c}\text { Deutsche } \\
\text { Homoeopathie Union } \\
\text { DHU-Arzneimittel } \\
\text { GmbH\&Co.KG } \\
\text { Germany }\end{array}$ & 55000 \\
\hline
\end{tabular}

As can be seen from the table, the prices of medicines of several manufacturing enterprises do not differ greatly from each other. Such a result leads to an increase in the possibility of choosing an assortment of sedative drugs among patients.

Also in the course of the research, the update index, which is one of the indicators of the assortment of drugs with a sedative effect, was determined. The renewal of sedative drugs for a certain period of time means different manifestations of this type of medication, and this indicator is evaluated by the renewal index. The update index will determine the update level of the assortment. This is determined by the ratio of drugs with a sedative effectirga to the total number of drugs registered in the last 3 years. For this, the following formula was used:

$K=Y a \cdot 100 \% / U=36 * 100 / 100$ 
According to:

$\boldsymbol{K}$ - update index of the assortment;

$\mathrm{Ya}$ - the amount of sedative drugs registered for a certain period of time;

U- the total amount of the assortment of sedative drugs.

It can be seen that the renewal index is $36 \%$, which means that the assortment of drugs with a sedative effectirga is updated to $36 \%$ in 3 years

During the course of the research process, a survey was conducted among the Pharmacists

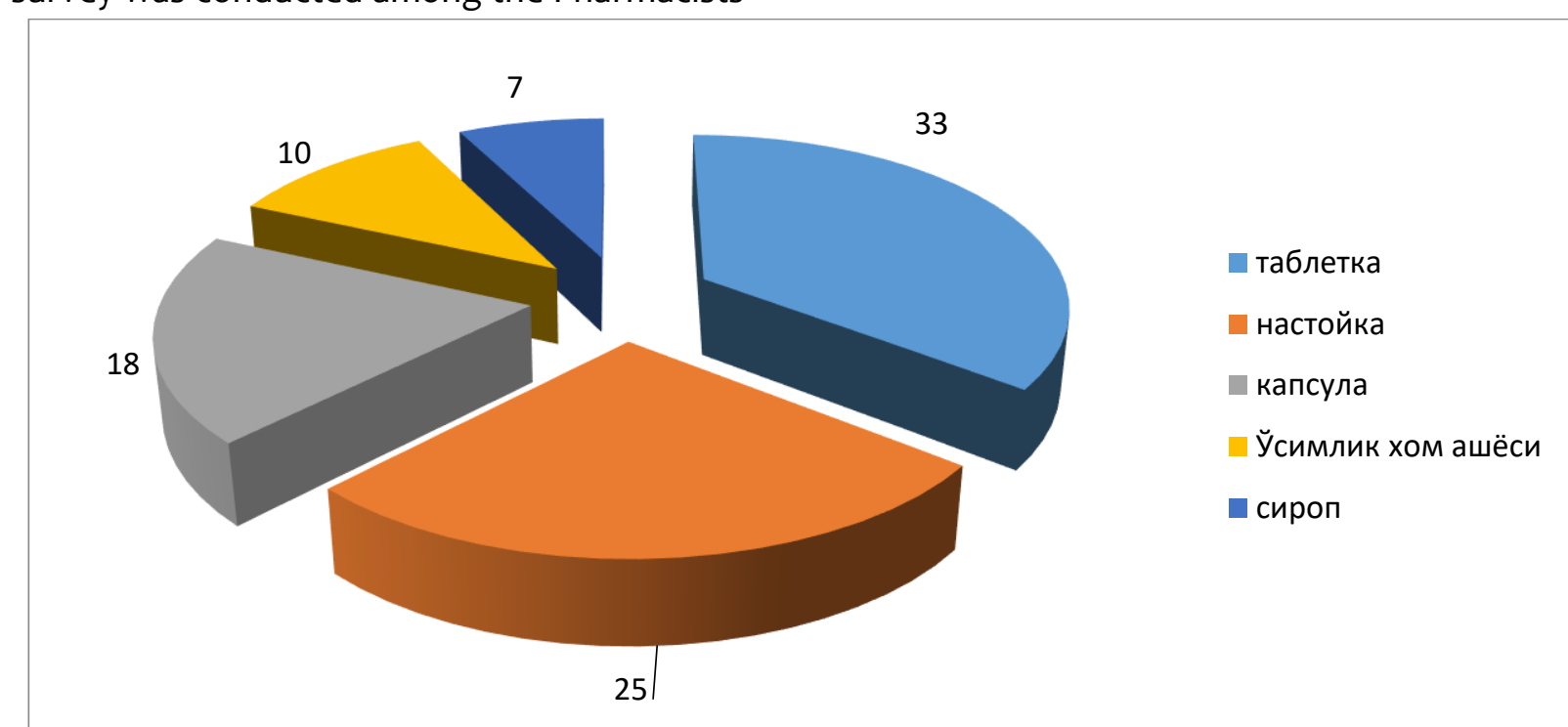

of the pharmacies whose names were mentioned above in order to investigate the demand of the population as a local producer, as well as the use of drugs. As a result of the survey, it was revealed that the population's need for sedative drugs was being met.

Also analyzed on the drug forms of sedative drugs. According to this, it was found that 33\% of the total assortment corresponds to the forms of syrups, $25 \%$ to nastoys, $18 \%$ to capsules, $10 \%$ to plant raw materials, $7 \%$ to syrups and the rest to drop-drug.

\section{CONCLUSIONS}

The content analysis of sedative drugs approved for use in the medical practice of the Republic of Uzbekistan was carried out and the following results were achieved:

1. It was found out that the significant share of sedative drugs (49\%) recorded in the
Republic of Uzbekistan corresponds to domestic production enterprises.

2. The forms of drugs from sedative drugs, such as nastoyka, drops, tabletka, capsules, syrup, prepared from plant raw materials, constitute the main part of the assortment.

3. In our republic, it was found that the assortment of sedative drugs, which are 
licensed for use in medical practice, has been significantly updated to $36 \%$ for domestic drugs.

4. When analyzing the drug forms of sedative drugs, it was found that $33 \%$ of the total assortment was treated with ointments, $25 \%$ with nastoys, $18 \%$ with capsules, $10 \%$ with plant raw materials, $7 \%$ with syrups and the remaining components were injected into the form of drops.

\section{REFERENCES}

1. Andreeva N.A. ; Ivchenko O.T ; T.I. Kabakova Marketing analysis of the market for sedative drugs. Pharmaceutical Sciences. Pyatigorsk 2011. -№30.- C604607.2. State Register of medicines and medical supplies - T., 2017-705 p

2. State Register of medicines and medical supplies - T., 2017-705 p

3. State Register of medicines and medical supplies - T., 2018-612 p

4. State Register of medicines and medical supplies - T., 2019-943. $\mathrm{p}$

5. www.uzpharm-control.uz 